\begin{tabular}{l|l}
\hline Potaice & e-ISSN: 2655-9404 p-ISSN: 2721-8376 \\
Vol. 3 No. 1, Februari 2020 & DOI: 10.20473/ntr.v3i1.15541 \\
\hline
\end{tabular}

Article history: Submitted 4 October 2019; Accepted 28 January 2020; Available online 1 February 2020.

\title{
Pertanggungjawaban Notaris Terhadap Pembuatan Akta Yang Menimbulkan Perkara Pidana
}

\author{
Gde Ancana, Pujo Setio Wardoyo dan Ema Diam Prihantono \\ radite85@yahoo.com \\ Universitas Airlangga
}

\begin{abstract}
Law is one of the facilities needed by all people to fill their lives. Required in the financial system launched in the era of globalization. These needs consist of laws, clear legal regulations and legal certainty and clear law enforcement actions from law enforcement. One legal officer in the civil field is a notary public official (Openbaar Ambtenaar) who must be professional because he represents the state that handles the duties and positions of leadership in making the deed as evidence to become the "Authentic Deed". Deed made by a notary public can be the legal basis for the status of property, rights and obligations of a person. Mistakes in notarial deeds can result in the deprivation of a person's rights or the imposition of someone on a necessity. By asking a notary in carrying out his profession, it does not need to be approved by legal norms or moral norms that are generally accepted, but must also comply with the legal provisions governing the professional code of ethics. Related to this notary code of ethics is very important in the development of national law which is important in terms of legal material, so in this case the notary code of ethics must be made so as to enable the notary to behave or research activities related to legal traffic to match what is outlined by the professional code of ethics and the code of ethics council must be approved by the judiciary against the code of ethics.

Keywords: Notary Responsibility; Deed; Criminal.
\end{abstract}

\begin{abstract}
Abstrak
Dalam kehidupan sehari-hari secara tidak sadar bahwa semua kegiatan manusia merupakan kegiatan hukum terutama pada sistem perekonomian. Kegiatan hukum tersebut berupa jual-beli, tukar-menukar barang, pemberian, dan lain sebagainya yang telah diatur dalam undang-undang, peraturan hukum yang jelas sehingga mempunyai kepastian hukum dalam menjalankan kegiatan tersebut. Pada bidang keperdataan, pejabat umum yang profesional dan perwakilan negara dalam membuat akta otentik sebagai alat bukti yang sempurna adalah Notaris. Hak dan kewajiban seseorang serta alas hukum atas status harta benda dapat dibuatkan akta akta otentik yang dibuat oleh Notaris. Adanya suatu kekeliruan dalam membuat suatu akta maka dapat menimbulkan akta tersebut dapat dibatalkan atau batal demi hukum. Oleh karenanya seorang notaris dalam menjalankan profesinya, tidak sekedar dibatasi oleh norma-norma hukum atau norma-norma kesusilaan yang berlaku secara umum, tetapi juga harus patuh terhadap ketentuan-ketentuan etika profesi yang diatur dalam kode etik profesi. Mengingat masalah kode etik notaris ini sangat penting di dalam pembangunan hukum nasional terutama dari segi materi hukum, maka dalam hal ini kode etik notaris harus dibuat sebaik mungkin agar dapat membatasi para notaris dalam bertingkah laku atau melakukan suatu perbuatan dalam lalu lintas hukum agar sesuai dengan apa yang digariskan oleh kode etik profesi serta dewan kehormatan kode etik harus menetapkan sanksi terhadap anggota yang melanggar kode etik.

Kata Kunci: Tanggung Jawab Notaris; Akta; Perkara Pidana.
\end{abstract}


66 | Gde Ancana, dkk: Pertanggungjawaban Notaris Terhadap...

\section{Latar Belakang}

Interaksi antara masyarakat baik dari sisi perbuatan hukum antara masyarakat satu dengan yang lainnya perlu dibuatkan suatu hubungan hukum agar memiliki legalitas, yang mana salah satu fungsi hukum adalah untuk memberikan kepastian hukum dalam kehidupan bermasyarakat. Keberadaan jabatan sebagai notaris sangat penting dan dibutuhkan masyarakat luas, mengingat fungsi notaris adalah sebagai Pejabat Umum yang membuat alat bukti tertulis berupa akta otentik. Dalam setiap perkara, baik perkara perdata maupun pidana, pasti tidak akan lepas dari pembuktian. Pembuktian merupakan sesuatu yang mutlak harus ada, sehingga menang atau kalahnya seorang penggugat atau tergugat tergantung kevalidan bukti-bukti yang diajukan ke pengadilan. Semakin kuat bukti, maka semakin kuat pula keyakinan seorang hakim mengenai kebenaran suatu perkara. Salah satu bentuk alat bukti adalah akta, dimana akta atau surat yang otentik bisa dikatakan sebagai alat bukti yang paling sempurna. ${ }^{1}$

Notaris sebagai Pejabat Umum (Openbaar Ambtenar) yang harus profesional karena mewakili negara menjalankan tugas dan fungsi jabatannya di dalam perubahan akta sebagai alat bukti yang berupa "Akta Otentik". Slaah satu perwujudan dari fungsi sosial Notaris adalah dalam memberikan keringanan biaya (honorarium) atau bahkan membebaskannya, jika dipandang perlu dan undangundang mengharuskan untuk itu bagi anggota masyarakat yang membutuhkan jasa Notaris tersebut dengan menunjukkan surat bukti keterangan tidak mampu dari kelurahan atau pejabat yang berwenang. ${ }^{2}$

Pada Pasal 15 ayat (1) UUJN No. 2 Tahun 2014 menyebutkan bahwa Notaris berwenang membuat akta otentik mengenai semua perbuatan, perjanjian, dan penetapan yan diharuskan oleh peraturan perundang-undangan dan/atau yang dikehendaki oleh yang berkepentingan untuk dinyatakan dalam akta otentik,

1 Baharudin, 'Kewenangan Pejabat Pembuat Akta Tanah (PPAT) Dalam Proses Jual Beli Tanah' [2014] Jurnal Hukum Universitas Bandar Lampung.[2].

2 AA Andi Prajitno, Apa Dan Siapa Notaris Di Indonesia? (Perwira Media Nusantara 2015).[2]. 
menjamin kepastian tanggal pembuatan akta, menyimpan akta, memberikan grosee, salinan dan kutipan akta, semuanya itu sepanjang pembuatan akta-akta itu tidak juga ditugaskan atau dikecualikan kepada pejabat lain atau orang lain uang ditetapkan oleh undang-undang. ${ }^{3}$

Yang dimaksud dengan pejabat umum (openbaar ambtenaar) dalam sistem hukum di negara Republik Indonesia satu-satunya adalah orang yang menjabat sebagai Notaris. Dengan dinamakan Notaris, juga termasuk semua pegawai yang ditugaskan oleh pemerintah untuk melakukan segala pekerjaan yang berhubungan dengan pekerjaan Notaris (Peraturan Peralihan Pasal 104). ${ }^{4}$

Fungsi akta otentik dalam hal pembuktian tentunya diharapkan dapat menjelaskan secara lengkap dalam proses pembuktian di persidangan sebagai bentuk pelaksanaan tanggung jawabnya karena pada proses peradilan berdasarkan hukum acara pidana, di dalamnya terdapat proses pembuktian, yang menekankan pada alat-alat bukti yang sah menurut Pasal 184 KUHAP, artinya dalam perkara pidana akta notaris merupakan alat bukti yang tidak mengikat penyidik dan hakim dalam pembuktian, atau bersifat bebas. Apabila dalam perkara perdata, akta otentik yang dikeluarkan oleh Notaris sebagai pejabat yang di angkat oleh pemerintah merupakan alat bukti yang bersifat mengikat dan memaksa, mengandung maksud hakim harus membenarkan akta otentik tersebut. Adapun akta notaris batal demi hukum apabila tidak memenuhi syarat subyektif dan syarat obyektif. ${ }^{5}$

Akta otentik sebagai alat bukti terkuat dan terpenuh mempunyai peranan penting dalam setiap hubungan hukum dalam kehidupan masyarakat. Melalui akta otentik yang menentukan secara jelas hak dan kewajiban, menjamin kepastian hukum, dan sekaligus diharapkan pula dapat dihindari terjadinya sengketa. Walaupun sengketa tersebut tidak dapat dihindari, dalam proses

3 ibid.[32].

4 ibid.

5 Liliana Tedjosaputro, Etika Profesi Notaris Dalam Penegakan Hukum Pidana (PT Bayu Indra Grafika 1997).[4]. 
penyelesaian sengketa tersebut, akta otentik yang merupakan alat bukti tertulis terkuat dan terpenuh memberi sumbangan nyata bagi penyelesaian perkara secara murah dan cepat. ${ }^{6}$

Akta yang dibuat dihadapan Notaris merupakan akta otentik yang memiliki kekuatan pembuktian yang sempurna yang artinya bahwa akta tersebut dibuat sesuai dengan keadaan dan kenyataan yang dilihat dihadapan seorang Notaris. Dalam pembuktian perdata bahwa yang termasuk dalam alat bukti yaitu alat bukti tulisan atau akta otentik sehingga hal tersebut dianggap sangat penting mengharuskan adanya pembuatan akta. ${ }^{7}$

Seorang notaris dalam menjalankan profesinya, tidak sekedar dibatasi oleh norma-norma hukum atau norma-norma kesusilaan yang berlaku secara umum, tetapi juha harus patuh terhadap ketentuan-ketentuan etika profesi yang diatur dalam kode etik profesi. Mengingat masalah kode etik notaris ini sangat penting di dalam pembangunan hukum nasional terutama dari segi materi hukum, maka dalam hal ini kode etik notaris harus dibuat sebaik mungkin agar dapat membatasi para notaris dalam bertingkah laku atau melakukan suatu perbuatan dalam lalu lintas hukum agar sesuai dengan apa yang digariskan oleh kode etik profesi serta dewan kehormatan kode etik harus menetapkan sanksi terhadap anggota yang melanggar kode etik karena menurut Soebekti bahwa fungsi dan tujuan kode etik dalam suatu kalangan profesi adalah menjunjung tinggi martabat profesi, dan menjaga atau memelihara kesejahteraan para anggotanya dengan mengadakan larangan-larangan. ${ }^{8}$

Dalam prakteknya terkadang Notaris tidak mempedoman pada ketentuan UU No. 2 Tahun 2014 tentang Undang-Undang Jabatan Notaris dalam menjalankan tugas dan jabatannya sebagai penjabat umum, karena masih terjadi permasalahan-

6 Penjelasan Atas Undang-undang Nomor 2 Tahun 2014 tentang Perubahan AtasUndang-Undang Nomor 30 Tahun 2004 tentang Jabatan Notaris, TLNRI Nomor 5491. 2014).[21].

7 Habib Adjie, Merajut Pemikiran Dalam Dunia Notaris Dan PPAT (Citra Aditya Bakti

8 Iwan Budisantoso, 'Diakses Pada 22 Agustus 2019.' (2019) <<www.kompasiana. com/2608/tanggung-jawab-profesinotaris-dalam-menjalankan-dan-menegakkan-hukum-di-indonesia>>. 
permasalahan dalam realisasi penandatanganan akta seperti pada saat pertemuan atau rapat yang tidak dihadiri oleh semua pihak, Akta yang bentuknya masih draft pada saat ditandatangani, dan lain sebagainya. Pada Kenyataannya sekarang akta-akta produk Notaris banyak yang bermasalah dan dipermasalahkan, hal ini terjadi dikarenakan ketidakpahaman pejabat hukum, selain karena sistem pendidikan formal yang dulunya dititikberatkan kepada praktek namun sekarang dititikberatkan kepada teori. Pembentukan karakter jiwa dari sosok seorang Notaris yang meliputi keteguhan mental, moral, iman, akhlak melalui penghayatan, pengamalan Etika Profesi (Etika jabatan) dan penguasaan materi dari pekerjaannya tidak ditanamkan secara optimal pada saat pendidikan, serta tidak ditunjang secara profesional. Artinya, pendidikan tentang teknis pembuatan akta serta penguasaan metri hukum, etika, penanaman, atau pembentukan karakter kurang mendapat perhatian yang serius, pendidikan Notaris sejak tahun 2000 hanya menitikberatkan pada akademik sistem atau teori.

\section{Notaris Sebagai Pejabat Umum Yang Bertanggung Jawab Dalam Pembuatan Akta Otentik}

Kata notaris berasal dari kata "Nota Literaria" yaitu "lettermark" atau "karakter", dengan mana para "notarii" tersebut menuliskan atau menggambarkan suatu "perkataan penuh" atau "lengkap". Untuk pertama kali nama "notarii" diberikan kepada orang-orang yang pekerjaannya mencatat atau menuliskan pidato yang diucapkan dahulu oleh "CATO (de Oudere)" dalam senat Romawi, dengan mempergunakan "abrevation" (tanda-tanda kependekan isi materi / resume) atau "Character", dalam dunia jurnalis disebut "stenographic". Kemudian pada abad ke-V dan abad ke-VI, nama notarii diberikan secara khusus kepada para penulis pribadi dari para kaisar, sehingga arti pada umumnya notarii hilang dan pada akhir abad ke Vperkataan notarii diartikan sebagai "hofbeambten" yang melakukan berbagai ragam pekerjaan konselarij Kasiran dan semata-mata pekerjaan administratif. "Hofbeambten" ada beberapa tingkatan, pekerjaan utama adalah menulis segala sesuatu yang dibicarakan dalam consistorium Kaisar pada 
acara rapat-rapat kenegaraan Para notarii yang mempunyai jabatan kedudukan tinggi tersebut tidak mempunyai persamaan dengan Notaris yang kita kenal pada masa sekarang, yang sama hanya namanya, akan tetapi institute dari tribunii notarii kekaisaran ini mempunyai pengaruh besar dalam terjadinya keberanaan Notaris sekarang ini. ${ }^{9}$

Notaris merupakan pejabat umum yang dalam menjalankan tugasnya wajib berpedoman pada etika notaris. Etika notaris yang dimaksud adalah kode etik dalam menjalankan suatu profesi supaya betul-betul mencerminkan pekerjaan bermoral, profesional, bermoral, dengan berorientasi pada keterampilan intelektual dengan argumentasi kritis dan rasional. ${ }^{10}$

Menjalankan jabatan profesi Notaris harus profesional artinya dalam praktek dituntut untuk bersikap/bertindak tegas, cepat, dan tanggap, teliti, jeli, tidak berpihak, sesuai peraturan perundang-undangan yang berlaku, sesuai dengan kenyatan atau keadaan yang sebenarnya, harus independen, serta tidak dipengaruhi oleh siapapun termasuk instansi eksekutif (pemerintah), legislatif (pembentuk undang-undang), dan yudikatif (peradilan). ${ }^{11}$

Pembuatan akta-akta Notaris berdasarkan permintaan dari seseorang/ subyek hukum dan dalam pembuatan akta telah diatur didalam UUJN yang mencakup pada awal akta, isi akta, dan akhir akta. Pasal 26, 27, 32, 33 dan 34 UUJN dibuat untuk melindungi akta-akta yang dibuat oleh notaris karena akta notaris merupakan dokumen negara.Menurut Sarman Hadi bahwa terkait Notaris bahwa: ${ }^{12}$ "Notaris bukanlah pihak dalam akta yang dibuat dihadapannya, karena tidak memihak. Notaris tidak mempunyai pihak, namun dapat memberikan jalan dalam jalur hukum yang berlaku, agar maksud pada pihak yang meminta bukti tertulis akan terjadinya hubungan hukum diantara para pihak, dapat dibantu melalui jalur hukum yang benar. Dengan demikian maksud para pihak tercapai

9 Prajitno (n 2)., Op.Cit.[12].

${ }^{10}$ Lumban Tobing, G.H.S,Peraturan Jabatan Notaris Reglement (Erlangga 1999).[48].

${ }_{11}$ Prajitno (n 2)., Op. Cit.[44].

${ }^{12}$ Koesbiono Sarman Hadi, 'Profesi Notaris Dalam Era Globalisasi, Tantangan Dan Peluang' (1996).[7]. 
sesuai dengan kehendak para pihak, di sinilah dituntut pengetahuan hukum yang luas dari seorang notaris untuk dapat meletakkan hak dan kewajiban para pihak secara proporsional".

Di Indonesia, Notaris juga mempunyai arti sebagai pejabat yang dalam menjalankan jabatannya dituntut profesional dibidangnya yaitu membuat keterangan atau membuat akta sebagai alat bukti tertulis yang mempunyai tugas dan fungsi sosial pula. Dalam hal membuat akta otentik yang diakui undang-undang maka Notaris berarti mempunyai kedudukan dan jabatan yang sangat mulia, memiliki harkat dan martabat yang sangat tinggi dan terhormat, karena jabatan ini adalah jabatan kepercayaan yang diberikan oleh pemerintah atas nama Negara untuk memenuhi kebutuhan masyarakat dalam bidang hukum keperdataan. Arti fungsi sosial dari Notaris memberikan keringanan biaya atau bahkan membebaskan biaya, jika masyarakat bersangkutan dapat mempertanggungjawabkan dengan menunjukkan surat bukti (keterangan) tidak mampu dari instansi yang berwenang. ${ }^{13}$

Menurut Pasal 1 ayat (1) disebutkan bahwa Notaris adalah pejabat umum yang berwenang untuk membuat akta otentik dan kewenangan lainnya sebagaimana dimaksud dalam Undang-Undang Ini. Sedanngkan pada Pasal 1 ayat (7) disebutkan bahwa akta notaris adalah akta otentik yang dibuat oleh atau dihadapan Notaris menurut bentuk dan tata cara yang ditetapkan dalam undangundang ini. Dan dijabarkan pada UUJN Nomor 2 Tahun 2014 Pasal 15 ayat (1), tertulis sebagai berikut "Notaris berwenang membuat akta otentik mengenai semua perbuatan, perjanjian, dan penetapan yang diharuskan oleh peraturan perundang-undangan dan/atau yang dikehendaki oleh yang berkepentingan untuk dinyatakan dalam akta otentik, menjamin kepastian tanggal pembuatan akta, menyimpan akta, memberikan grosse, salinan dan kutipan akta, semuanya itu sepanjang pembuatan akta-akta itu tidak juga ditugaskan atau dikecualikan kepada pejabat lain atau orang lain yang ditetapkan oleh undang-undang.

${ }^{13}$ Prajitno (n 2)., Op.Cit.[37]. 
72 | Gde Ancana, dkk: Pertanggungjawaban Notaris Terhadap...

Pasal 1868 BW berbunyi "Suatu akta otentik ialah suatu akta yang di dalam bentuk yang ditentukan oleh undang-undang, dibuat oleh atau dihadapan pegawai-pegawai umum yang berkuasa untuk itu ditempat dimana akta dibuatnya". Berdasarkan uraian bunyi pasal-pasal dari 2 (dua) undangundang yang masih berlaku tersebut, maka dapat disimpulkan pejabat yang dimaksud Pasal 1868 BW satu-satunya adalah Notaris, walaupun Pasal 1868 BW hanya menerangkan apa yang dinamakan :akta otentik", akan tetapi tidak menerangkan apa itu "pegawai umum", juga tidak diteranngkan tempat dimana ia berhak atau batas kewenangannya sedemikian, sampai dimana batas-batas haknya dan bagaimana menurut hukum yang dimaksud. Dapat disimpulkan produk akta Notaris dan jabatan Notaris adalah akta otentik dan pejabat umum yang dimaksud adalah Pasal 1868 BW bertalian dengan UUJN Nomor 2 Tahun 2014 Pasal 1 ayat (1) dan ayat (7) serta Pasal 15 ayat (1). Adalah satu keharusan untuk menjadikan Notaris sebagai satu-satunya pegawai umum atau pejabat umum, sehubungan dengan definisi dari akta otentik yang diberikan oleh Pasal 1868 BW tersebut, akan tetapi Notaris bukan pegawai negeri (karena tidak mempunyai Nomor Induk Kepegawaian/NIP) dan juga bukan organ pemerintah oleh karenanya tidak berhak atas gaji pensiun dari negara. Notaris tidak digaji akan tetapi menerima imbalan jasanya dari yang meminta jasanya. ${ }^{14}$

Berdasarkan uraian diatas maka diambil kesimpulan bahwa notaris adalah pejabat umum (bukan pegawai negeri) yang diberi kewenangan untuk membuat akta-akta dan kewenangan lainnya yang telah ditentukan dalam Undang-Undang Jabatan Notaris Nomor 2 Tahun 2014. Notaris diberi amanat oleh Negara untuk membantu Negara dalam hal administrasi dalam hal melakukan perbuatan hukum tertentu yang berdasarkan kebutuhan dari masyarakat. Namun tidak semua pejabat umum disebut Notaris.

14 ibid. 


\section{Penerbitan Akta Notaris Yang Menimbulkan Perkara Pidana}

Istilah akta berasal dari bahasa Belanda yaitu Akte. ${ }^{15}$ Dalam mengartikan akta ini ada dua pendapat yaitu. Pendapat pertama mengartikan akta sebagai surat dan pendapat kedua mengartikan akta sebagai perbuatan hukum. Beberapa sarjana yang menganut pendapat pertama yang mengartikan akta sebagai surat antara lain Pitlo mengartikan akta sebagai berikut: "surat yang ditandatangani, diperbuat untuk dipahami sebagai bukti dan untuk dipergunakan oleh orang untuk keperluan siapa surat itu dibuat" ${ }^{16}$

Akta otentik merupakan bukti yang sempurna bagi kedua belah pihak dan ahli warisnya serta sekalian orang yang mendapatkan hak daripadanya. Dengan demikian ini berarti bahwa isi akta tersebut oleh Hakim dianggap benar selama ketidakbenarannya tidak dapat dibuktikan. ${ }^{17}$ Akta otentik tidak memerlukan pengakuan dari pihak yang bersangkutan agar mempunyai kekuatan pembuktian. Terhadap pihak ketiga, akta tersebut tidak mempunyai kekuatan pembuktan yang sempurna, melainkan hanya bersifat alat pembuktian yang penilaiannya diserahkan kepada kebijaksanaan Hakim. ${ }^{18}$

Merujuk ketentuan Pasal tersebut pejabat umum yang dimaksud adalah notaris. Otensitas dari akta itu bersumber dari Pasal 1 ayat (1) Jo Pasal 15 ayat (1) Undang-Undang No. 2 Tahun 2014 Tentang Jabatan Notaris, akta otentik adalah akta notaril yang dibuat dihadapan Notaris menurut bentuk dan tata cara yang ditetapkan dalam Undang-Undang ini, sehingga akta yang di buat oleh Notaris mempunyai sifat otentik, otensitasnya bukan oleh karena dibuat demikian, akan tetapi oleh karena akta itu dibuat oleh atau di hadapan pejabat umum, seperti yang dimaksud dalam Pasal 1868 BW.

Dasar adanya tindak pidana adalah asas legalitas sedangkan dasar dapat dipidananya pembuat adalah asas kesalahan. Ini berarti bahwa pembuat

15 Sidah, Kekuatan Pembuktian Akta Di Bawah Tangan Yang Dilegalisasi Oleh Notaris (Magister Kenotariatan Universitas Diponegoro 2010).

16 Pitlo, Pembuktian Dan Daluwarsa (Internusa 1986).[52].

17 M Nur Rasaid., Hukum Acara Perdata (Sinar Grafika 2005).[38].

18 ibid.[38-39]. 
74 | Gde Ancana, dkk: Pertanggungjawaban Notaris Terhadap...

tindak pidana hanya akan dipidana jika ia mempunyai kesalahan dalam melakukan tindakan pidana tersebut. Kapan seseorang dikatakan mempunyai kesalahan merupakan hal yang menyangkut masalah pertanggungjawaban pidana. Seseorang mempunyai kesalahan bilamana pada waktu melakukan tindak pidana, dilihat dari segi kemasyarakatan ia dapat dicela oleh karena perbuatan tersebut. Selanjutnya Sudarto menyatakan bahwa, menurut beliau disini berlaku asas "tiada pidana tanpa kesalahan" (keine strafe ohne schuld atau geen straf zonder schuld atau nulla poena sine culpa). "Culpa" disini dalam arti luas, meliputi juga kesengajaan. Kesalahan, yang dimaksud adalah keadaan jiwa seseorang yang melakukan perbuatan dan perbuatan yang dilakukan itu sedemikian rupa, sehingga orang itu patut dicela. Seorang notaris bisa saja terlibat dalam pertanggungjawaban pidana dan mungkin saja dapat dimintakan pertanggungjawaban pidana apabila memenuhi unsur-unsur yang dilarang menurut hukum. Adanya kemampuan bertanggungjawab pada si pembuat, hubungan batin antara si pembuat dan perbuatannya yang berupa kesengajaan (dolus) atau kealpaan (culpa) dan tidak adanya alasan penghapusan kesalahan atau tidak ada alasan pemaaf. ${ }^{19}$

\section{Tindakan - Tindakan Hukum Notaris Yang Terlibat Perkara Tindak Pidana Pemalsuan Akta Notaris.}

Pelaksanaan profesi yang benar mengharuskan notaris untuk dapat menghindarkan diri dalam pekerjaan dan perilakunya terhadap setiap jenis persaingan yang tidak adil, di samping itu juga harus menghormati jurisdiksi sesama rekan notaris lainnya, menghindari penurunan imbalan, periklanan pribadi dan lain sebagainya, bila hal tersebut dilanggar akan merusak citra dan nama baik yang seyogyanya diperoleh.

${ }^{19}$ Hilda Sophia Wiradiredja, 'Pertanggungjawaban Pidana Notaris Dalam Pembuatan Akta Yang Didasarkan Pada Keterangan Palsu Dihubungkan Dengan Undang-Undang Nomor 30 Tahun 2004 Tentang Jabatan Notaris Jo Undang-Undang Nomor 2 Tahun 2014 Dan KUHP' (2015) 32 Jurnal Wawasan Hukum. 
Notaris sebagai pejabat publik berbeda dengan advokat. Advokat dalam melaksanakan tugasnya adalah hanya untuk memuaskan salah satu pihak, sedangkan notaris dalam melaksanakan tugasnya adalah untuk memuaskan para pihak atau kedua belah pihak. Sehingga notaris dalam hal ini harus mementingkan segala kepentingan para pihak dan dapat memberikan pelayanan yang baik bagi para pihak yang menggunakan jasanya. Putusan Mahkamah Agung Perkara Nomor 1014 K/PID/2013 bahwa sikap jujur, amanah, mandiri, saksama, dan tidak berpihak yang harusnya dimiliki oleh notaris tidak terlihat sama sekali karena notaris mengikuti kemauan dan kepentingan Robby Sumampao yang juga menjadi terpidana dalam kasus ini, tanpa mempertimbangkan kepentingan pihak lain.

Tindakan malpraktek yang kadang dilakukan oleh notaris adalah tidak membacakan akta di hadapan klien dan klien tidak bertanda tangan dihadapan Notaris pada akta-akta yang dibuat oleh notaris. Dalam Putusan Mahkamah Agung Perkara Nomor 1014 K/PID/2013 ini dapat dilihat dari dakwaan penuntut umum yang menyebutkan bahwa rapat dilaksanakan tidak dihadiri oleh seluruh anggota pembina dan seluruh anggota pengawas yayasan yang memutuskan untuk melakukan perubahan terkait anggaran dasar yayasan, hal ini dapat menunjukkan bahwa notaris tersebut tidak melaksanakan sebagaimana tertuang dalam UUJN yaitu tidak membacakan akta yang dibuat kepada para pihak, sehingga notaris tersebut telah melanggar Pasal 44 Undang-undang Nomor 2 Tahun 2014. Pasal 44 ayat (1) yang berbunyi “Segera setelah akta dibacakan, Akta tersebut ditandatangani oleh setiap penghadap, saksi, dan notaris, kecuali apabila ada penghadap yang tidak dapat membubuhkan tanda tangan dengan menyebutkan alasannya." Kurangnya pengalaman yang dimiliki oleh seorang notaris juga merupakan salah satu penyebab ketidaksengajaan notaris tersebut terlibat dalam melakukan tindak pidana.

Putusan atas permasalahan ini terjadi pada tahun 2008 sedangkan UndangUndang Nomor 30 Tahun 2004 Tentang Jabatan Notaris belum mengatur secara tegas terkait hukuman bagi seorang notaris namun setelah diberlakukannya Undang-Undang Nomor 2 Tahun 2014 Tentang Perubahan UUJN Nomor 
76 Gde Ancana, dkk: Pertanggungjawaban Notaris Terhadap...

30 Tahun 2004 nyatanya masih belum juga mengatur secara tegas mengenai pelanggaran-pelanggaran dan kesalahan-kesalahan yang dilakukan dilakukan oleh Notaris sehingga harus mempertanggung jawabkan perbuatannya dalam perkara perdata maupun dalam perkara pidana. Diharapkan adanya peraturan yang jelas dan dapat memberikan perlindungan hukum kepada para notaris serta dapat menjalankan tugasnya dengan baik sebagai pejabat umum, sehingga notarisnotaris tidak mudah untuk ditarik dalam permasalahan yang sebenarnya notaris tersebut tidak perbuat. Selain itu agar tidak terjadi perdebatan lagi ketentuan yang cocok digunakan apabila notaris terlibat tindak pidana terkait dengan akta yang diterbitkannya apakah Pasal 263 KUHP, Pasal 264 KUHP, atau Pasal 266 KUHP. Karena sering terjadi banyak tafsir mengenai surat dengan akta otentik bahwa keduanya dapat ditafsirkan sama.

Notaris seringkali dalam praktiknya terlibat dengan perkara hukum baik sebagai saksi maupun sebagai tersangka. Keterlibatan Notaris dalam perkara hukum disebabkan adanya kesalahan pada akta yang dibuatnya, baik karena kesalahan Notaris itu sendiri maupun kesalahan para pihak atau salah satu pihak yang tidak memberikan keterangan atau dokumen yang sebenarnya (tidak adanya iktikad baik dari para pihak atau salah satu pihak) atau telah ada kesepakatan antara Notaris dengan salah satu pihak yang menimbulkan kerugian pada pihak lain (Notaris turut serta melakukan tindak kejahatan). Berhubungan dengan akta yang dibuatnya, Notaris harus dimintakan pertanggungjawabanpidananya karena menimbulkan kerugian bagi para pihak atau salah satu pihak. Notaris pada dasarnya tidak dapat dimintakan pertanggungjawaban pidana, karena Notaris hanya bertanggung jawab pada sisi formal pembuatan akta. Terkait hal tersebut jika adanya dugaan keterlibatan pejabat Notaris terhadap perbuatan melawan hukum dan turut serta melakukan kejahatan dalam pemalsuan dokumen. Yang mana dalam hukum di Indonesia pemalsuan terhadap sesuatu merupakan salah satu bentuk tindak pidana yang telah diatur dalam kitab undang-undang hukum pidana (KUHP). Ketentuan mengenai turut melakukan dan membantu melakukan dapat dilihat dalam Pasal 55 (turut melakukan) dan Pasal 56 Kitab Undang- 
Undang Hukum Pidana ("KUHP) (membantu melakukan). ${ }^{20}$ R. Soesilo dalam bukunya yang berjudul Kitab Undang-Undang Hukum Pidana (KUHP) Serta Komentar-Komentarnya Lengkap Pasal Demi Pasal 5 menjelaskan mengenai apa yang dimaksud dengan "orang yang turut melakukan" (medepleger) dalam Pasal 55 KUHP. Menurut R. Soesilo, “turut melakukan” dalam arti kata "bersama- sama melakukan". Sedikit-dikitnya harus ada dua orang, ialah orang yang melakukan (pleger) dan orang yang turut melakukan (medepleger) peristiwa pidana. Di sini diminta bahwa kedua orang itu semuanya melakukan perbuatan pelaksanaan, jadi melakukan anasir atau elemen dari peristiwa tindak pidana itu. misalnya hanya melakukan perbuatan persiapan saja atau perbuatan yang sifatnya hanya menolong, sebab jika demikian, maka orang yang menolong itu tidak masuk "medepleger" akan tetapi dihukum sebagai "membantu melakukan" (medeplichtige) dalam Pasal 56 KUHP. Sedangkan mengenai Pasal 56 KUHP, R. Soesilo menjelaskan bahwa orang "membantu melakukan" jika ia sengaja memberikan bantuan tersebut, pada waktu atau sebelum (jadi tidak sesudahnya) kejahatan itu dilakukan. Bila bantuan itu diberikan sesudah kejahatan itu dilakukan, maka orang tersebut melakukan perbuatan "sekongkol" atau "tadah" melanggar Pasal $480 \mathrm{KUHP}$, atau peristiwa pidana yang tersebut dalam Pasal 221 KUHP. ${ }^{21}$

Keadilan korektif berfokus pada pembetulan sesuatu yang salah. Apabila suatu pelanggaran dilanggar atau kesalahan dilakukan, maka keadilan korektif berusaha memberikan kompensasi yang memadai bagi pihak yang dirugikan; jika suatu kejahatan telah dilakukan, maka hukuman yang pantas perlu diberikan kepada si pelaku. Bagaimanapun, ketidakadilan akan mengakibatkan terganggu tentang "kesetaraan" yang sudah mapan atau telah terbentuk. Keadilan korektif bertugas membangun kembali kesetaraan tersebut. Uraian tersebut nampak bahwa keadilan korektif merupakan wilayah peradilan sedangkan keadilan distributif

${ }^{20}$ Abdul Jalal dan Sri Wahyuningsih, 'Keterlibatan Pejabat Notaris Terhadap Perbuatan Melawan Hukum Dan Turut Serta Melakukan Tindak Kejahatan Dalam Pemalsuan Dokumen' (2018) 5 Akta.

21 ibid. 
78 Gde Ancana, dkk: Pertanggungjawaban Notaris Terhadap...

merupakan bidangnya pemerintah. ${ }^{22}$

Aristoteles menekankan perlu dilakukan pembedaan antara vonis yang mendasarkan keadilan pada sifat kasus dan yang didasarkan pada watak manusia yang umum dan lazim, dengan vonis yang berlandaskan pandangan tertentu dari komunitas hukum tertentu. Pembedaan ini jangan dicampuradukkan dengan pembedaan antara hukum positif yang ditetapkan dalam undang-undang dan hukum adat. Berdasarkan pembedaan Aristoteles, dua penilaian yang terakhir itu dapat menjadi sumber pertimbangan yang hanya mengacu pada komunitas tertentu, sedangkan keputusan serupa yang lain, kendati diwujudkan dalam bentuk perundangundangan, tetap merupakan hukum alam jika bisa didapatkan dari fitrah umum manusia. ${ }^{23}$

Berdasarkan uraian tersebut dengan menggunakan teori keadilan maka dapat disimpulkan bahwa rasa keadilan itu belum terpenuhi. Jaksa Penuntut Umum meyakini notaris tersebut terbukti melakukan tindak pidana Pasal 264 ayat (1) KUHP dengan pidana dengan kurungan penjara selama 1 (satu) tahun sedangkan Majelis Hakim menjatuhkan hukuman pidana penjara selama 8 bulan. Hukuman 8 bulan penjara ini sangat ringan dibandingkan dengan ancaman hukuman didalam Pasal 264 ayat (1) KUHP yaitu 8 tahun penjara. Hakim memiliki kebebasan dalam memutus perkara namun hukuman 8 bulan penjara sangatlah tidak adil bagi pihak yang dirugikan oleh notaris. Hukuman ini dapat dikatakan tidak memiliki efek jera bagi notaris tersebut. Berdasarkan teori keadilan yang dikemukakan oleh Aristoteles, putusan ini sama sekali tidak memenuhi keadilan korektif yang mana tidak memberikan kompensasi yang memadai bagi pihak yang dirugikan. Hakim hanya memutus berdasarkan ketentuan peraturan perundang-undangan tanpa dibarengi dengan pertimbangan hati nurani. Untuk memenuhi rasa keadilan, hakim dalam memutus perkara ini sebaiknya menjatuhkan hukuman penjara 2/3 dari ancaman Pasal yang didakwakan apalagi bukti-bukti yang diajukan oleh jaksa penuntut umum sah dan meyakinkan.

\footnotetext{
22 ibid.

23 ibid.[26-27].
} 
Dengan demikian dapat dikatakan bahwa seorang notaris dapat dimintakan pertanggungjawabannya secara perdata berupa sanksi atau ganti rugi terhadap pihak yang dirugikannya, pertanggungjawaban secara administrasi, pertanggungjawaban secara kode etik profesi notaris, bahkan pertanggungjawaban secara pidana berupa pidana penjara atau kurungan atas perbuatan hukum yang dilakukannya. Dalam kasus ini notaris telah memenuhi tanggung jawabnya secara pidana sebagai salah satu bentuk ganti rugi atas perbuatan yang dilakukannya. Sanksi pidana yang dijatuhkan pada notaris ini dapat dijadikan dasar untuk meminta pertanggungjawaban secara perdata, administratif, maupun kode etik.

\section{Kesimpulan}

Berdasarkan Putusan Mahkamah Agung Perkara Nomor 1014 K/PID/2013 dijelaskan bahwa jaksa penuntut umum (JPU) memberikan dakwaannya kepada notaris dengan Pasal 264 ayat (1) dengan tuntutan 1 (satu) tahun kurungan penjara sedangkan Majelis Hakim memutus bahwa Notaris tersebut secara sah dan meyakinkan telah melakukan tindak pidana pemalsuan akta otentik dan menjatuhkan pidana selama 8 (delapan) bulan kurungan. Pada kasus ini Pasal yang digunakan dalam menjerat tindak pidana Notaris tersebut dirasa cukup tepat yaitu Pasal 264 KUHP merupakan pasal tindak pidana memalsukan aktaakta otentik yang dimana Notaris adalah pejabat umum yang diberi kewenangan oleh Undang-Undang untuk membuat akta otentik. Belum adanya pengaturan secara jelas dan rinci mengenai bentuk-bentuk pelanggaran pidana bagi Notaris yang tertuang dalam Undang-undang Nomor 2 Tahun 2014 tentang Perubahan Atas Undang-undang Nomor 30 tahun 2004 tentang Jabatan Notaris sehingga diperlukan adanya sanksi atau aturan sebagai bentuk tanggung jawab notaris yang lebih jelas juga agar adanya suatu kepastian hukum bagi para notaris.

Pemalsuan akibat hukum terhadap akta otentik yang dibuat oleh Notaris yaitu akta yang dibuat menjadi cacat hukum karena diyakini bahwa notaris tersebut dengan sengaja membuat keterangan tidak benar ke dalam akta otentik. Dengan adanya kejadian tersebut maka pihak yang merasa dirugikan 
80 | Gde Ancana, dkk: Pertanggungjawaban Notaris Terhadap...

dapat membuktikan bahwa akta tersebut cacat hukum dihadapan Majelis Hakim Pengadilan Negeri karena pada dasarnya bahwa akta dapat dibatalkan berdasarkan putusan pengadilan.

Kesalahan-kesalahan Notaris yang berakibat pada terlibatnya ke dalam perkara tindak pidana dalam prakteknya notaris berpihak dan hanya memenuhi kepentingan salah satu pihak, dokumen yang diajukan oleh para penghadap tidak benar dan hal tersebut diketahui oleh Notaris, Notaris tidak membacakan akta dihadapan para pihak, fungsi organisasi dalam hal pengawasan terhadap notaris tidak optimal, dan tidak adanya kepastian hukum dalam hal melindungi Notaris dalam menjalankan jabatannya sebagai pejabat umum.

\section{Daftar Bacaan}

\section{Buku}

Habib Adjie, Merajut Pemikiran Dalam Dunia Notaris Dan PPAT (Citra Aditya Bakti 2014).

Hadi KS, 'Profesi Notaris Dalam Era Globalisasi, Tantangan Dan Peluang' (1996).

Lumban Tobing, G.H.S,Peraturan Jabatan Notaris Reglement (Erlangga 1999).

Pitlo, Pembuktian Dan Daluwarsa (Internusa 1986).

Prajitno AAA, Apa Dan Siapa Notaris Di Indonesia? (Perwira Media Nusantara 2015). Rasaid. MN, Hukum Acara Perdata (Sinar Grafika 2005).

Sidah, Kekuatan Pembuktian Akta Di Bawah Tangan Yang Dilegalisasi Oleh Notaris (Magister Kenotariatan Universitas Diponegoro 2010).

Tedjosaputro L, Etika Profesi Notaris Dalam Penegakan Hukum Pidana (PT Bayu Indra Grafika 1997).

\section{Jurnal}

Abdul Jalal dan Sri Wahyuningsih, 'Keterlibatan Pejabat Notaris Terhadap Perbuatan Melawan Hukum Dan Turut Serta Melakukan Tindak Kejahatan Dalam Pemalsuan Dokumen' (2018) 5 Akta.

Baharudin, 'Kewenangan Pejabat Pembuat Akta Tanah (PPAT) Dalam Proses Jual 
Beli Tanah' [2014] Jurnal Hukum Universitas Bandar Lampung.

Hilda Sophia Wiradiredja, ‘Pertanggungjawaban Pidana Notaris Dalam Pembuatan Akta Yang Didasarkan Pada Keterangan Palsu Dihubungkan Dengan Undang-Undang Nomor 30 Tahun 2004 Tentang Jabatan Notaris Jo Undang-Undang Nomor 2 Tahun 2014 Dan KUHP' (2015) 32 Jurnal Wawasan Hukum.

\section{Laman}

Iwan Budisantoso, 'Diakses Pada 22 Agustus 2019.' (2019) < ‘www.kompasiana. com/2608/tanggung-jawab-profesinotaris-dalam-menjalankan-danmenegakkan-hukum-di-indonesia>>.

\section{Perundang-undangan}

Undang-undang Nomor 2 Tahun 2014 tentang Perubahan Atas Undang-Undang Nomor 30 Tahun 2004 tentang Jabatan Notaris, TLNRI Nomor 5491.

Kitab Undang-Undang Hukum Perdata.

Kitab Undang-Undang Hukum Pidana.

How to cite: Gde Ancana, Pujo Setio Wardoyo dan Ema Diam Prihantono, 'Pertanggungjawaban Notaris Terhadap Pembuatan Akta Yang Menimbulkan Perkara Pidana' (2020) Vol. 3 No. 1 Notaire. 
82 | Gde Ancana, dkk: Pertanggungjawaban Notaris Terhadap...

--Halaman ini sengaja dikosongkan-- 